\title{
Influenza virus hemagglutinin as a vaccine antigen produced in bacteria
}

\author{
Violetta Sączyńska ${ }^{凶}$ \\ Institute of Biotechnology and Antibiotics, Warsaw, Poland
}

\begin{abstract}
Recombinant subunit vaccines based on hemagglutinin proteins produced in bacteria (bacterial HAs) are promising candidates for enhancing the supply of vaccines against influenza, especially for a pandemic. Over 20 years after the failure to obtain the antigen with native HA characteristics in the early 1980's, there are increasing data on successful production of HA proteins in bacteria. The vast majority of bacterial HAs have been based on the HA1 subunit of HA expressed separately or as a component of conjugate vaccines, but those based on the ectodomain and the HA2 subunit have also been reported. The most of HAs have been efficiently expressed as insoluble aggregates called inclusion bodies. Refolded and purified proteins were extensively studied for structure, the ability to bind to sialic acid-containing receptors, antigenicity, immunogenicity and efficacy. The results from these studies contradict the view that glycosylation determines the correct structure of the hemagglutinin, as they proved that bacterial HAs can be valuable vaccine antigens when appropriate folding and purification methods are applied to rationally designed proteins. The best evidence for success in bacterial production of protective HA is that vaccines based on proprietary Toll-like Receptor (VaxInnate) and bacteriophage Q $\beta$-VLPs (Cytos Biotechnology) technologies have been advanced to clinical studies.
\end{abstract}

Key words: recombinant influenza hemagglutinin, recombinant influenza vaccine, subunit influenza vaccine, bacterial hemagglutinin, prokaryotic protein production

Received: 29 May, 2014; revised: 22 August, 2014; accepted: 22 August, 2014; available on-line: 08 September, 2014

\section{INTRODUCTION}

Research on subunit vaccines against influenza responds to the demand for technology that would allow the efficient production of the vaccine in a relatively short time, contrary to the traditional egg- or cell culture-based manufacturing (Osterholm et al., 2012). The availability of such technology would be useful for seasonal vaccine production, especially as vaccine antigens need to be matched to circulating strains of influenza virus on an annual basis. This is of special importance in case of a pandemic flu threat, as was highlighted by the emergence of the 2009 H1N1 swine influenza virus pandemic (H1N1pdm09). Currently, the highly pathogenic avian influenza virus (HPAIV) H5N1 poses a permanent pandemic threat as there is still a risk that the virus will acquire the ability of direct transmission between humans. Moreover, emerging disease outbreaks often of epizootic characteristics are accompanied by high infectivity and mortality among birds, including domestic avian species. Therefore, the development of efficacious influenza vaccines against H5N1 HPAIV is of veterinary and public health significance. An important advantage of the subunit vaccines against HPAIVs is that their usage does not interfere with epidemiological surveillance, as the serological differentiation of naturally vaccinated animals/flocks from vaccinated ones is possible. The socalled DIVA (differentiation of infected from vaccinated animals) strategy is a prerequisite for vaccinations against avian influenza (Suarez, 2005).

The obvious candidates for the production of subunit vaccines against influenza are the major surface glycoproteins of influenza viruses: hemagglutinin (HA) and neuraminidase (NA), since they induce a specific humoral immune response that provides immunity or recovery after the infection (McMurry et al, 2007). Immunity induced by HA and NA varies considerably (Johansson et al., 1989; Sylte \& Suarez, 2009) because of different roles they play in the life cycle of influenza viruses. By binding to sialic acid residues of host cell receptors, HA allows internalization of the influenza viruses by endocytosis, and then mediates the fusion of viral and cellular membranes leading to the release of viral RNA to the cytoplasm and virus replication (Skehel \& Wiley, 2000). $\mathrm{NA}$ is an enzyme that cleaves terminal sialic acid residues from the oligosaccharide chain which determines the release of progeny virus from infected cells and thereby the virus spread (Lamb \& Choppin, 1983). Antibodies against HA generated both during infection and vaccination have the ability to neutralize influenza viruses (Wilson \& Cox, 1990). In contrast, anti-NA antibodies, referred to as infection permissive, do not prevent a viral infection and act at a later infection stage. Therefore, HA is considered as the main constituent of subunit vaccines, while NA as an additional component enhancing vaccine effectiveness (Johansson \& Brett, 2007). $\mathrm{HA}$ is also an immunodominant antigen in conventional vaccines against influenza (Sylte \& Suarez, 2009).

Hemagglutinin is synthesized as a single polypeptide chain, the so-called precursor HA (HA0), containing a hydrophobic signal sequence, HA1 and HA2 subunits separated by the cleavage site for proteolytic enzymes

e-mail: saczynskav@iba.waw.pl

Abbreviations: HA, hemagglutinin; HA1(HA2), subunit $1(2)$ of hemagglutinin; VLP, virus- like particle; H1N1pdm09, 2009 H1N1 pandemic; HPAIV, highly pathogenic avian influenza virus; DIVA, differentiation of infected from vaccinated animals; NA, neuraminidase; rHA, recombinant hemagglutinin; Mab, monoclonal antibody; TLR, Toll-like Receptor; APC, antigen presenting cell; $\mathrm{gH}$, globular domain; ssRNA, single stranded RNA; HI, hemagglutination inhibition; $\mathrm{HP}$, highly pathogenic 
(Wilson \& Cox, 1990). The apolar region of the HA2 subunit adjacent to the cleavage site is referred to as a fusion peptide (Skehel et al., 2001). HA is classified as an integral membrane protein with a large hydrophilic domain on the external surface of the membrane, a small hydrophobic transmembrane domain, and a hydrophilic cytoplasmic domain on the internal side of the membrane (Wilson et al., 1981). The transmembrane and cytoplasmic domains are formed by $\mathrm{C}$-terminal fragments of the HA2 subunit. Posttranslationally, HA undergoes host-cell dependent glycosylation and is cleaved to subunits connected by a disulfide bridge. Cleavage of HAO is a prerequisite for protein activation, which determines infectivity of influenza viruses (Skehel \& Wiley, 2000).

Up to date, crystal structures of several HAs have been solved. All of them share a similar three-dimensional structure. The protein consists of a globular domain formed by the HA1 subunit and the stem domain formed largely by the HA2 subunit, but also by amino acid sequences from the $\mathrm{N}$ - and C-termini of the HA1 subunit (Wilson et al., 1981; Ha et al., 2002). The globular domain of HA contains the receptorbinding subdomain, by which the virus binds to the host cell, while the fusion of viral and endosomal membranes is mediated by the stem domain (Wilson et al., 1981; Skehel \& Wiley, 2000). The HA2 subunit of the stem is responsible for the formation and stability of the HA homotrimer and its anchorage in the lipid envelope of influenza viruses (Wilson et al., 1981). Cleavage of HA results in structural rearrangements (Chen et al., 1998) such as upon reduction of the $\mathrm{pH}$ in the endosome to $\sim 5$, the protein adopts a fusogenic conformation in which the fusion peptide is exposed, binds to the endosomal membrane and fusion takes place (Skehel \& Wiley, 2000).

The globular domain of HA comprises epitopes, which are targeted by antibodies neutralizing virus infectivity by interference with binding of viruses to the host cell receptors (Wiley et al., 1981; Bizebard et al., 1995; Fleury et al., 1999). Antibodies to the stem domain are able to neutralize the virus infectivity by blocking membrane fusion (Okuno et al., 1993; Ekiert et al., 2009; Sui et al., 2009). Antibodies against the HA1 subunit crosslinking globular domains of the HA trimer could also have the ability to prevent membrane fusion (BarbeyMartin et al., 2002). Due to the variability and susceptibility to mutations (Shih et al., 2007), the globular domain is considered as an immunogenic HA fragment for subtype-specific vaccine production. In contrast, the stem region is relatively well conserved among different HA subtypes (Krystal et al., 1982), and therefore is seen as the target for the universal vaccine development (Pica \& Palese, 2013).

\section{CHALLENGES OF BACTERIAL HEMAGGLUTININ PRODUCTION}

The first research on HA protein expression in bacterial cells (the bacterial HA) was undertaken in the early 1980's. Attempts to obtain direct expression of HA proteins failed because of the protein instability in bacterial cells similar to that observed for other complex heterologous proteins expressed bacterially at that time (Davis et al., 1981). For efficient expression, the fragments of influen$\mathrm{za}$ virus HA were produced in fusion with bacterial proteins: $\beta$-galactosidase (Davis et al., 1981) or trpLE' (Davis et al., 1983). Studies on the antigenici- ty and immunogenicity of the obtained bacterial HA showed that the protein structures are quite different from those displayed by the native protein (Davis et al., 1981; 1983; Nayak et al., 1985). At the same time, recombinant HAs (rHAs) with biological and structural characteristics similar to native viral $\mathrm{HA}$ were obtained in the eukaryotic (animal cell cultures, yeast) expression systems (Nayak et al., 1985).

The potential difficulties of efficient production of properly folded bacterial HA, such as the presence of three hydrophobic regions (signal sequence, fusion peptide, transmembrane domain) and lack of glycosylation, were already seen at the first attempts to obtain the antigen by direct expression in prokaryotic cells (Davis et al., 1981; 1983; Nayak et al., 1985). In bacteria, large hydrophobic regions of proteins are recognized as misfolded and undergo degradation (Baneyx \& Mujacic, 2004), and this limits or prevents bacterial expression of transmembrane proteins. Besides, such proteins are usually lethal when expressed in bacterial strains commonly used in the production of biopharmaceuticals. Although the strains of bacteria intended for the production of transmembrane proteins are currently available (Miroux \& Walker, 1996; Dumon-Seignovert et al., 2004), hydrophobicity will always decrease expression levels. On the other hand, experience with HA expression in mammalian, insect and yeast cells suggests that soluble HA proteins based on the ectodomain of viral HA can be valuable immunogens (Saelens et al., 1999; Wei et al., 2008; Bosch et al., 2010; Cornelissen et al., 2010; Weldon et al., 2010; Loeffen et al., 2011).

Glycosylation is known to play an important role in HA folding during viral multiplication in host cells (Roberts et al., 1993). For this reason, the widely accepted view over the years was that HA glycosylation determines the correct structure of the protein, and the lack of glycosylation is the cause of failures in obtaining valuable vaccine antigens with the bacterial expression system (Davis et al., 1983; Nayak et al., 1985). On the other hand, it is known that oligosaccharides attached to viral HA can modulate protein antigenicity by epitope masking and interfering with their recognition by the respective antibodies (Skehel et al., 1984; Wiley \& Skehel, 1987). More recently, experimental data concerning the impact of glycosylation status on conformation, host cell receptor binding activity, antigenicity, immunogenicity, and efficacy of the HA proteins have been published (Bright et al., 2003; Wang et al., 2009; de Vries et al., 2012). Altogether these data justify the view that the removal of structurally nonessential glycans on viral surface glycoproteins (Wang et al., 2009), or avoiding glycosylation (Xuan et al., 2011) may constitute effective approach for vaccine design against influenza. The vaccine strategy relying on nonglycosylated HA protein has been accomplished with bacterially produced antigens. However, it should be noted that obtaining glycosylated proteins by overexpression in bacteria is possible owing to the discovery of the N-glycosylation system in Campylobacter jejuni (Wacker et al., 2002). Indeed, glycosylation of HA1 subunit of H1 HA in recombinant E. coli containing the glycosylation system of $C$. jejuni has been confirmed (Farahmand et al., 2012).

The main challenge of bacterial HA production is the development of a refolding method, which would allow to obtain the antigen similar to viral HA even though the HA protein can be efficiently produced in bacteria cells as a nonglycosylated protein, in addi- 
Table 1. Bacteria-expressed proteins based on HA1 subunit of HA

\begin{tabular}{|c|c|c|c|}
\hline HA protein & Influenza virus strain & & Reference \\
\hline$<\mathrm{H} 5(1-340 \mathrm{aa})>$ & $\mathrm{A} / \mathrm{H} 5 \mathrm{~N} 1 / \mathrm{Ck} / \mathrm{Hatay}$ & A/Chicken/Hatay/04 & Shen et al., 2008 \\
\hline $\mathrm{H} 5(1-346 \mathrm{aa})^{*}$ & $\mathrm{~A} / \mathrm{H} 5 \mathrm{~N} 1 / \mathrm{VN}, \mathrm{HK}, \mathrm{THA}$ & $\begin{array}{l}\text { consensus sequence of } \\
\text { A/Vietnam/1194/04 } \\
\text { A/Hong Kong/483/97 } \\
\text { A/Thailand/LFPN-2004/04 }\end{array}$ & Chiu et al., 2009 \\
\hline $\begin{array}{l}\mathrm{H} 1(1-330 \mathrm{aa})^{* *} \\
\mathrm{H} 5(1-330 \mathrm{aa})^{* *}\end{array}$ & $\begin{array}{l}\text { A/H1N1pdm09/CA07 } \\
\text { A/H5N1/NN }\end{array}$ & $\begin{array}{l}\text { A/California/07/09 } \\
\text { A/Vietnam/1203/04 }\end{array}$ & $\begin{array}{l}\text { Khurana et al., 2010b } \\
\text { Khurana et al., 2011b }\end{array}$ \\
\hline $\mathrm{H} 1(1-320 \mathrm{aa})^{* * *}$ & $\begin{array}{l}\text { A/H1N1pdm09/CA07 } \\
\text { A/H1N1pdm09/CA04 }\end{array}$ & $\begin{array}{l}\text { A/California/07/09 } \\
\text { A/California/04/09 }\end{array}$ & $\begin{array}{l}\text { Khurana et al., 2011a } \\
\text { Khurana et al., 2011b }\end{array}$ \\
\hline \multirow[t]{3}{*}{$\mathrm{H} 5(1-320 \mathrm{aa})^{* * *}$} & $\mathrm{~A} / \mathrm{H} 5 \mathrm{~N} 1 / \mathrm{VN}$ & A/Vietnam/1203/04 & $\begin{array}{l}\text { Khurana et al., } 2011 \mathrm{a}, \mathrm{b} \\
\text { Verma et al., } 2012\end{array}$ \\
\hline & $\mathrm{A} / \mathrm{H} 5 \mathrm{~N} 1 / \mathrm{IN}$ & A/Indonesia/5/05 & Khurana et al., 2011a, b \\
\hline & A/H5N1/WS/Mong & $\begin{array}{l}\text { A/Whooperswan/ } \\
\text { Mongolia/244/05 }\end{array}$ & Verma et al., 2012 \\
\hline $\begin{array}{l}\mathrm{H} 7(1-320 \mathrm{aa})^{* * *} \\
\mathrm{H} 3(1-320 \mathrm{aa})^{* * * *}\end{array}$ & $\begin{array}{l}\text { A/H7N7/NL } \\
\text { A/H3N2/WIS } \\
\text { A/H3N2/VIC }\end{array}$ & $\begin{array}{l}\text { A/Netherlands/219/03 } \\
\text { A/Wisconsin/15/09 } \\
\text { A/Victoria/210/09 }\end{array}$ & $\begin{array}{l}\text { Khurana et al., } 2011 \mathrm{~b} \\
\text { Khurana et al., } 2011 \mathrm{~b} \\
\text { Khurana et al., } 2011 \mathrm{~b}\end{array}$ \\
\hline H5(28-320 aа) & $\mathrm{A} / \mathrm{H} 5 \mathrm{~N} 1 / \mathrm{VN}$ & A/Vietnam/1203/04 & Khurana et al., $2011 \mathrm{~b}$ \\
\hline $\mathrm{H} 1(63-286 \mathrm{aa})^{*}$ & A/H1N1pdm09/Mex & A/Mexico/4603/09 & $\begin{array}{l}\text { Aguilar-Yáñez et al., } 2010 \\
\text { DuBois et al., } 2011\end{array}$ \\
\hline $\begin{array}{l}\mathrm{H} 1(63-286 \mathrm{aa})^{*} \\
2 \times \mathrm{H} 1(63-286 \mathrm{aa})^{*}\end{array}$ & A/H1N1pdm09 & N/A & Sánchez-Arreola et al., 2013 \\
\hline $\begin{array}{l}\mathrm{H} 1(57-264 \mathrm{aa})^{*} \\
/ \mathrm{H} 1(57-272 \mathrm{aa}) / / \\
/ \mathrm{H} 1(50-280 \mathrm{aa}) /\end{array}$ & A/H1N1pdm09/CA04 & A/California/04/09 & Xuan et al., 2011 \\
\hline H3(91-261 аa) & $\mathrm{A} / \mathrm{H} 3 \mathrm{~N} 2 / \mathrm{PC}$ & A/Port Chalmers/1/73 & Jeon \& Arnon, 2002 \\
\hline $\mathrm{HA}(61-287$ aа) & $\mathrm{A} / \mathrm{H} 1 \mathrm{~N} 1, \mathrm{H} 3 \mathrm{~N} 2, \mathrm{H} 5 \mathrm{~N} 1$ & $\begin{array}{l}\text { H1N1 - consensus seq } \\
+\mathrm{H} 3 \mathrm{~N} 2, \mathrm{H} 5 \mathrm{~N} 1 \text { epitopes }\end{array}$ & Dukhovlinov et al., 2013 \\
\hline
\end{tabular}

Legend to Table $1:<>$ purified by electroelution from SDS/PAGE gels, at least partially denatured; *properly folded monomers; **largely trimers/ oligomers from properly folded monomers; ${ }^{* * *}$ more stable oligomers; / / refolding efficiency and biochemical properties not satisfactory.

tion devoid of the regions (signal sequence, anchoring peptide) participating in the formation of higher-order structures of HA protein during its biosynthesis in host cells (Wilson et al., 1981). The efforts to preserve the native structure of the vaccine HA are reasonable as most epitopes targeted by neutralizing antibodies are conformational ones (Wiley et al., 1981). Moreover, results from studies on rHAs from eukaryotic expression system indicate that, in addition to a proper conformation of the HA monomer, the oligomerization status of HA antigen has a significant influence on the level and the quality of the immune response (Wei et al., 2008; Weldon et al., 2010). The conclusion is that the trimeric/oligomeric antigens are undoubtedly more immunogenic than monomeric ones, but the oligomerization may also impact on the repertoire of induced antibodies (Wilson \& Cox, 1990; Wei et al., 2008; Weldon et al., 2010). In order to obtain the soluble HA proteins forming desired stable oligomeric structures, ectodomain-based antigens produced in mammalian or insect cells have been expressed together with intentionally added foreign trimerizing sequences (Wei et al., 2008; Bosch et al., 2009; Weldon et al., 2010; Loeffen et al., 2011).

\section{BACTERIAL HEMAGGLUTININS}

The increasing data on three-dimensional structures of various-origin HAs in conjunction with the possibilities afforded by in silico modeling as well as the development of protein bioengineering and biotechnology have opened up new opportunities for the design of HA proteins to be expressed in bacterial cells. The currently ongoing research is focused on HA1 subunit-, HA2 subunit- and ectodomain-based bacterial HAs. Proteins containing the HA1 subunit or its fragment are intended to provide immunity against influenza viruses of a specified subtype. Despite of the presence of conservative neutralizing epitopes in the HA2 subunit (Okuno et al., 1993; Ekiert et al., 2009; Sui et al., 2009), the longer HA immunogens can also be classified as the subtype-specific, because the globular domain inhibits immune recognition of HA stem region presumably through masking or due to immunodominance (Steel et al., 2010). As highly variable antigenic sites of the HA1 subunit are immunodominant, the problem to provide cross-protection even against related influenza virus strains by vaccination with HA-based vaccines has also been encountered. Attempts to provide intra-subtype cross-protection with 
Table 2. Conjugate vaccines with bacteria-expressed HA globular domain

\begin{tabular}{|c|c|c|c|}
\hline HA protein & Influenza virus strain & & Reference \\
\hline [ H1(101-276 aa) ] & $\mathrm{A} / \mathrm{H} 1 \mathrm{~N} 1 / \mathrm{PR} 8$ & A/Puerto Rico/8/34 & Song et al., 2008 \\
\hline \multicolumn{4}{|l|}{$\begin{array}{l}\left\{\begin{array}{l}\left.\mathrm{H} 1(53-324 \mathrm{aa})^{*}\right\} \\
\left\{\mathrm{STF} 2 . \mathrm{H} 1(53-324 \mathrm{aa})^{*}\right\}\end{array}\right.\end{array}$} \\
\hline \multicolumn{4}{|l|}{$\begin{array}{l}\mathrm{H} 1(62-284 \mathrm{aa})^{*} \\
\text { STF2.H1(62-284 aa)* }\end{array}$} \\
\hline $\begin{array}{l}\text { STF2.H1 }(62-284 \mathrm{aa})^{*} \\
\text { VAX125 }\end{array}$ & $\mathrm{A} / \mathrm{H} 1 \mathrm{~N} 1 / \mathrm{SI}$ & A/Solomon Island /3/06 & $\begin{array}{l}\text { Song et al., } 2008 \\
\text { Treanor et al., } 2010 \\
\text { Taylor et al., } 2011\end{array}$ \\
\hline $\begin{array}{l}\text { STF2.H1(63-285 aa)* } \\
\text { VAX128A }\end{array}$ & $\mathrm{A} / \mathrm{H} 1 \mathrm{~N} 1 \mathrm{pdm09/CA07}$ & A/California/07/09 & $\begin{array}{l}\text { Liu et al., } 2011 \\
\text { Hong et al., } 2013 \\
\text { Taylor et al., } 2012\end{array}$ \\
\hline $\begin{array}{l}\text { STF2R3.H1(63-285 aa)* } \\
\text { VAX128B }\end{array}$ & & & $\begin{array}{l}\text { Liu et al., } 2011 \\
\text { Taylor et al., } 2012\end{array}$ \\
\hline $\begin{array}{l}\text { STF2R3.2 } \times \text { H1 } 1(63-285 \text { aa)* } \\
\text { VAX128C }\end{array}$ & & & $\begin{array}{l}\text { Liu et al., } 2011 \\
\text { Taylor et al., } 2012\end{array}$ \\
\hline STF2.H5(62-284 aa)* & $\mathrm{A} / \mathrm{H} 5 \mathrm{~N} 1 / \mathrm{VN}$ & A/Vietnam/1203/04 & Song et al., 2009 \\
\hline | STF2R0.H5(62-284 aa) | & & & Song et al., 2009 \\
\hline STF2R3.H5(62-284 aa)* & & & $\begin{array}{l}\text { Song et al., } 2009 \\
\text { Liu et al., 2012; }\end{array}$ \\
\hline STF2R3.2×H5(62-284 aa)* & & & Liu et al., 2012 \\
\hline $\begin{array}{l}\text { STF2R3.H5(62-284 aa)* } \\
\text { STF2R3.2×H5(62-284 aa)* }\end{array}$ & $\mathrm{A} / \mathrm{H} 5 \mathrm{~N} 1 / \mathrm{IN}$ & A/Indonesia/5/05 & Liu et al., 2012 \\
\hline $\begin{array}{l}\text { STF2R3.H5(62-284 aa)* } \\
\text { STF2R3.2×H5(62-284 aa)* }\end{array}$ & $\mathrm{A} / \mathrm{H} 5 \mathrm{~N} 1 / \mathrm{AN}$ & A/Anhui/1/05 & Liu et al., 2012 \\
\hline $\begin{array}{l}\text { Group A (4 disulfide bridges) } \\
\text { gH1_A } 1^{*} \div \mathrm{gH} 1 \_A 2^{*}\end{array}$ & A/H1N1/PR8m.a. & $\begin{array}{l}\text { mouse adapted (m.a.) } \\
\text { A/Puerto Rico/8/34 }\end{array}$ & Jegerlehner et al., 2013 \\
\hline \multicolumn{4}{|l|}{$\begin{array}{l}\text { Group B (2 disulfide bridges) } \\
\text { gH1_B1* } \div \mathrm{gH} 1 \_B 4^{*}\end{array}$} \\
\hline \multicolumn{4}{|l|}{$\begin{array}{l}\text { Group C (1 disulfide bridge) } \\
{\left[\mathrm{gH} 1 \_\mathrm{C} 1\right] \div\left[\mathrm{gH} 1 \_\mathrm{C} 5\right]}\end{array}$} \\
\hline \multicolumn{4}{|l|}{$\begin{array}{l}\mathrm{Q} \beta-\mathrm{gH} 1 \_\mathrm{A} 1 \div \mathrm{A} 2 \mathrm{Vs} \\
\mathrm{Q} \beta-\mathrm{gH} 1 \_\mathrm{B} 1 \div \mathrm{B} 3 \\
\mathrm{Q} \beta-\mathrm{gH} 1 \_\mathrm{B} 4\end{array}$} \\
\hline$\underset{Q \beta-g H 1 \_A}{\mathrm{gH} 1 \_A}$ & A/H1N1pdm09/CA04 & A/California/04/09 & Jegerlehner et al., 2013 \\
\hline $\mathrm{Q} \beta-\mathrm{gH} 5 \_\mathrm{A}$ & $\mathrm{A} / \mathrm{H} 5 \mathrm{~N} 1 / \mathrm{VN}$ & A/Vietnam/1203/04 & Jegerlehner et al., 2013 \\
\hline & $\mathrm{A} / \mathrm{H} 5 \mathrm{~N} 1 / \mathrm{IN}$ & A/Indonesia/5/05 & \\
\hline$Q \beta-g H 1 \_A V$ & $\mathrm{~A} / \mathrm{H} 1 \mathrm{~N} 1 /$ Bris & A/Brisbane/59/07 & \\
\hline$Q \beta-g H_{3} \_A$ & $\mathrm{~A} / \mathrm{H} 3 \mathrm{~N} 2 /$ Uru & A/Uruguay/716/07 & \\
\hline$Q \beta-g H$ FluB_A & B/Bris & B/Brisbane/3/07 & \\
\hline $\begin{array}{l}\mathrm{gH} 1 \_A^{*} \\
Q \beta-g H 1 \_A \\
Q \beta(p G l u)-g H 1 \_A\end{array}$ & A/H1N1pdm09/CA07 & A/California/07/09 & Skibinski et al., 2013 \\
\hline Gcf(131-230 aa) - H1(62-284 aa) & A/H1N1/PR8 & A/Puerto Rico/8/34 & Park \& Chang, 2012 \\
\hline
\end{tabular}

Legend to Table 2: [ ] misfolded; \{ $\}$ refolding efficiency not satisfactory; *properly folded; STF2 - type 2 flagellin of Salmonella typhimurium; STF2. $\mathrm{H} 1(\mathrm{H} 5)$, STF2R3.H1(H5), STF2R3.2xH1(H5), STF2R0.H5 - STF:HA fusion proteins in C-term, R3, R3.2xHA and R0 formats, respectively; R - replacement of the D3 (R3) or D0 (R0) domain of STF2 with HA protein; R3.2 $\times$ H1 $(2 \times \mathrm{H} 5)$ - two HA protein copies per molecule, one in place of the D3 domain, the second one fused to the C-terminus of STF2; || low TLR5 activity; $\mathrm{gH}$ - globular domain; $\mathrm{v}_{\mathrm{gH}}$ proteins covalently linked to E. coli produced $\mathrm{Q} \beta$-VLPs derived from bacteriophage $\mathrm{Q} \beta$ with ssRNA inside; ${ }^{\mathrm{s}}$ soluble; insinsoluble; ${ }^{1} \mathrm{gH}$ proteins covalently linked to $\mathrm{Q} \beta$ (pGlu)-VLPs devoid of ssRNA; Gcf — respiratory syncytial virus $G$ protein core fragment. 
Table 3. Bacteria-expressed proteins based on HA ectodomain

\begin{tabular}{|c|c|c|c|}
\hline HA protein & Influenza virus strain & & Reference \\
\hline $\begin{array}{l}\mathrm{H} 1(1-480 \mathrm{aa})^{*} \\
\mathrm{H} 1-50 \mathrm{kDa}\end{array}$ & $\mathrm{A} / \mathrm{H} 1 \mathrm{~N} 1 \mathrm{pdm09/CA07}$ & A/California/07/09 & Khurana et al., 2010b \\
\hline $\mathrm{H} 5-60 \mathrm{kDa}$ & $\mathrm{A} / \mathrm{H} 5 \mathrm{~N} 1 / \mathrm{VN}$ & A/Vietnam/1203/04 & Biesova et al., 2009 \\
\hline $\mathrm{H} 5-63 \mathrm{kDa}$ & $\mathrm{A} / \mathrm{H} 5 \mathrm{~N} 1 / \mathrm{THA}$ & A/Thailand/HA20/05 & Horthongkham et al., 2007 \\
\hline msyB:H5 - 97 kDA & $\mathrm{A} / \mathrm{H} 5 \mathrm{~N} 1 / \mathrm{Ck} / \mathrm{Gd}$ & A/Chicken/Guangdong/01 & Xie et al., 2009 \\
\hline
\end{tabular}

Legend to Table 3: *properly folded monomers

HA1 subunit containing immunogens focus on both the antigen design and adjuvants. Data from studies on immunogenicity of different glycosylation forms of HA proteins indicated that the glycosylation state does not seem to significantly affect the breadth of cross-protection (Bright et al., 2003; Wang et al., 2009; de Vries et al., 2012). The possibility to elicit broader protection by the development of effective vaccine composition was demonstrated with MF59 adjuvant applied to inactivatedH5N1 vaccines (Khurana et al., 2010a).

A quite new approach to obtaining a vaccine which would provide intra- or even inter-subtype protection is engineering the antigen that could focus the immune response to the aforementioned neutralizing epitopes in the HA2 subunit (Okuno et al., 1993; Ekiert et al., 2009; Sui et al., 2009). For this purpose, the cross-reactive HA2 determinants are being unmasked by removal of the immunodominant globular domain from HA proteins, resulting in expression of so-called stalk or stem domainbased immunogens (Steel et al., 2010; Bommakanti et al., $2010 ; 2012)$. On the other hand, universal influenza vaccines based on a single or a few conservative epitopes of influenza virus proteins, including $\mathrm{HA}$ and produced as proteins consisting of repeated sequences of selected epitopes have also been obtained by expression in bacterial cells (Li et al., 2003; Rudolph \& Ben Yedidia, 2011; Atsmon et al., 2012). The epitope-based vaccines are beyond the scope of this review.

\section{Design}

The bacterially produced HA proteins based on the HA1 subunit, expressed separately or as a component of conjugate vaccines as well as those based on the ectodomain and the HA2 subunit of HA are listed in the Tables 1-4 together with the virus strains from which the HA sequences were derived. The fragment of H5 HA containing the signal sequence and the HA1 subunit expressed with (Chiu et al., 2009) or without (Shen et al., 2008) basic amino acids of the cleavage site were produced by overexpression in $E$. coli. The shorter fragments of the HA1 subunit containing the globular domain, expressed in bacteria with the signal sequences, were obtained by Khurana and coworkers (2010b; 2011a; 2011b) and Verma and coworkers (2012). The vaccine project was inspired by results showing that large fragments of the HA1 subunit encompassing the receptor-binding subdomain are bound by broadly neutralizing human monoclonal antibodies (Mabs) from H5N1 recovered individuals, and by polyclonal convalescent sera (Khurana et al., 2009).

Other designs of subtype-specific vaccines against influenza were based on the assumptions that the isolated globular domain comprises all well-defined antibody-recognizing sites (Xuan et al., 2011), and is able to better expose the receptor-binding region of HA than subunit HA1 or ectodomain (Jeon \& Arnon, 2002) and furthermore, has much less surface hydrophobicity than the entire HA ectodomain, so it could be expressed with higher efficiency than larger protein fragments (Aguilar-Yáñez et al., 2010). To obtain a more universal immunogen, the HA1 subunit fragment containing immunogenic epitopes of various HA subtypes was produced (Dukhovlinov et al., 2013).

The first group of conjugate vaccines against influenza produced by overexpression in bacterial cells, listed in Table 2, consists of fusion proteins containing the type 2 flagellin from Salmonella typhimurium (STF2), which is the ligand of Toll-like Receptor (TLR) type 5. It was hypothesized that providing the antigen and TLR5 signaling to the same antigen presenting cells (APCs) would lead to enhancement of antigen presentation as well as to the induction of both humoral and cellular responses (Liu et al., 2011). For this purpose, three various-length fragments comprising the globular domain were produced. Thereafter, two of them were fused to the C-terminus of STF2 by a flexible linker (Song et al., 2008). Subsequently, the other formats of conjugated vaccines, denoted R0, R3, R3.2 $\times$ HA, which differed in the number of copies and the placement of HA molecules in the fusion proteins, were developed (Song et al., 2009; Liu et al., 2011, 2012).

Conjugate vaccines of another group (Table 2) were generated by coupling of bacterial HAs to Q $\beta$-VLPs i.e. bacterially expressed virus-like particles derived from bacteriophage Q $\beta$ (Jegerlehner et al., 2013; Skibinski et al., 2013). The fragments of the HA1 subunit were chosen for conjugation as they contain the globular domain $(\mathrm{gH})$ comprising most of the protein's neutralizing epitopes, and are expected to fold independently from the rest of the HA molecule (Jegerlehner et al., 2013). It was hypothesized that conjugation of $\mathrm{gH}$ protein to $\mathrm{Q} \beta$ VLPs would enhance its immunogenicity and efficacy through a number of mechanisms (Skibinski et al., 2013). Presentation of $\mathrm{gH}$ proteins on the surface of VLPs in a repetitive fashion might be a strong activation signal for $\mathrm{B}$ cells, and the particulate nature of VLPs makes them likely to be more efficiently taken up by APCs. In addition, the bacterial single stranded RNA (ssRNA), which is incorporated into VLPs during recombinant expression, is a ligand of TLR type 7. Thus, it could activate APCs and B cells upon VLP uptake. Eleven $\mathrm{gH}$ proteins containing four (group A), two (group B) or one (group C) disulfide bridge(s) per molecule, and comprising intact secondary structure elements were rationally designed and produced (Jegerlehner et al., 2013). Proteins from the $\mathrm{A}$ and $\mathrm{B}$ groups were subsequently coupled in vitro 
Table 4. Bacteria-expressed proteins based on HA2 subunit of HA

\begin{tabular}{|c|c|c|c|}
\hline HA protein & Influenza virus strain & & Reference \\
\hline$<\mathrm{H} 5\left(347-522 \mathrm{aa}^{1}\right)>$ & A/H5N1/Ck/Hatay & A/Chicken/Hatay/04 & Shen et al., 2008 \\
\hline$(1-185$ aа $) \times$ & N/A & & Kim et al., 2011 \\
\hline$(23-185 \text { aa })^{x \circ}$ & N/A & & Chen et al., 1999 \\
\hline$(38-175 \text { aа) })^{x \circ}$ & N/A & & Chen et al., 1995 \\
\hline $\mathrm{H} 3 \mathrm{HA} 6{ }^{2 \mathrm{M} \mathrm{WT}+}$ & $\mathrm{A} / \mathrm{H} 3 \mathrm{~N} 2 / \mathrm{HK}$ & A/Hong Kong/2/68 & Bommakanti et al., 2010 \\
\hline \multicolumn{4}{|l|}{$\mathrm{H} 3 \mathrm{HA} 6{ }^{2 \mathrm{M} \mathrm{m} 1+}$} \\
\hline \multicolumn{4}{|l|}{$\mathrm{H} 3 \mathrm{HA}^{2}{ }^{2 \mathrm{M} \mathrm{m} 2+}$} \\
\hline $\mathrm{H} 3 \mathrm{HA} 6^{2 \mathrm{M}+}$ & A/H3N2/Phil & A/Philippines/2/82 & Bommakanti et al., 2010 \\
\hline $\mathrm{H} 1 \mathrm{HA} 6^{2 \mathrm{M}+\mathrm{O}}$ & A/H1N1/PR8 & A/Puerto Rico/8/34 & Bommakanti et al., 2012 \\
\hline $\mathrm{H} 1 \mathrm{HA} 6{ }^{2 \mathrm{M} \mathrm{m} 3+}$ & $\mathrm{A} / \mathrm{H} 1 \mathrm{~N} 1 / \mathrm{NC}$ & A/New Caledonia/20/99 & \\
\hline $\mathrm{H} 1 \mathrm{HA} 6{ }^{2 \mathrm{M} \mathrm{m} 4+}$ & A/H1N1pdm09/CA07 & A/California/07/09 & \\
\hline $\mathrm{H} 1 \mathrm{HA} 0 \mathrm{HA} 6^{3 \mathrm{M}+\bullet}$ & A/H1N1/PR8 & A/Puerto Rico/8/34 & Bommakanti et al., 2012 \\
\hline
\end{tabular}

Legend to Table 4: < > purified by electroelution from SDS-PAGE gels, at least partially denatured; ${ }^{1}$ full-length $\mathrm{HA}$ numbering; ${ }^{\mathrm{x}}$ low $\mathrm{pH}$, fusogenic

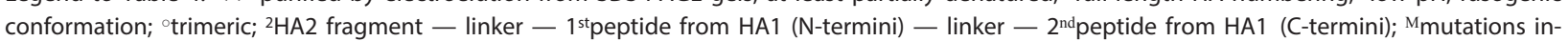
troduced to remove exposed hydrophobic patches and stabilize the neutral $\mathrm{pH}$ conformation; ${ }^{W T}$ wild-type; ${ }^{+}$neutral $\mathrm{pH}$, pre-fusion conformation; ${ }^{\mathrm{m} 1}$ disulfide mutant 1 ; ${ }^{\mathrm{m} 2}$ disulfide mutant $2 ;{ }^{\mathrm{m} 3}$, m4additional, sequence related mutations; ${ }^{3}{ }^{\text {st }}$ peptide from HA1 (N-termini) - linker -2 nd peptide from HA1 (C-termini) — HA2 fragment, mutation in the cleavage site; •largely aggregated.

to $\mathrm{Q} \beta$-VLPs to form various $\mathrm{Q} \beta$-gH proteins. The HA fragment was also used to design the composite vaccine against both influenza and respiratory syncytial viruses (Park \& Chang, 2012).

Although the vast majority of bacterially produced antigens are based on the HA1 subunit, there are also reports on bacterial expression of the proteins containing sequences from HA1 and HA2 subunits of HA (Table 3). Thereby, the resultant immunogens comprise neutralizing epitopes of both HA subunits. The 1-480 aa fragment of the H1pdm09 HA ectodomain, expressed with the signal sequence (Khurana et al., 2010b) as well as full-length ectodomain of $\mathrm{H} 5 \mathrm{HA}$ (Biesova et al., 2009) were produced. Based on the sequences of HA from H5N1 HPAIVs, the $63 \mathrm{kDa}$ immunogen (Horthongkham et al., 2007) as well as soluble $97 \mathrm{kDA}$ fusion protein of HA fragment with a chaperonin msyB (Xie et al., 2009) were obtained.

Bacterial expression of HA2 subunit-based proteins (Table 4) for vaccination purposes was reported exceptionally, and the rationale was to obtain the immunogen comprising conservative neutralizing epitopes. Variouslength proteins containing exclusively HA2 subunit sequences from the HA ectodomain were bacterially produced (Chen et al., 1995; 1999; Shen et al., 2008; Kim et al., 2011). Alternatively, Bommakanti et al. (2010, 2012) rationally designed the stem domain immunogens containing a large portion of the HA2 subunit, and two fragments of HA1 subunit considered to be interacting with HA2 regions in the whole $\mathrm{HA}$ molecule. The project resulted in the expression of the prototype constructs, denoted HA6 and HAOHAG.

\section{Refolding and purification}

The vast majority of bacterially produced HA proteins, listed in Tables 1-4, were expressed with affinity 6xHis-tags as insoluble aggregates called inclusion bodies. Besides purification, obtaining of the vaccine with such a form of HA requires the protein to be dissolved and refolded. Experimental data were published indicating that the majority, but not all of refolded and purified bacterial HAs, adopt the correct conformation. With various procedures aiming to obtain recombinant HA1 subunit (Table 1), it was shown that the effectiveness of protein refolding strongly depends on the applied method (Chiu et al., 2009). In the case of rHAs largely consisting of the globular domain (Tables: 1, 2), it has been proven that the refolding effectiveness and/or its efficiency substantially depends on the HA fragment which has been selected for the vaccine antigen design (Song et al., 2008; Xuan et al., 2011; Jegerlehner et al., 2013). Moreover, these results highlighted the role of the secondary structure elements flanking the globular domain (Song et al., 2008) as well as of the disulfide bond formation (Jegerlehner et al., 2013) for proper folding of the isolated globular domain. It was also shown that some of the globular domain-based proteins (Tables: 1, 2) are able to adopt the proper conformation when they were expressed separately, in a fusion with flagellin (Song et al., 2008) as well as a monomeric or dimeric protein connected by a flexible linker (Sánchez-Arreola et al., 2013).

The structure and/or antigenicity studies showed that some of HA1 subunit-based bacterial HAs, listed in Tables: 1, 2, as well as the 1-480 aa fragment of HA ectodomain (Table 3) display well preserved conformational neutralizing epitopes essential for the induction of the protective immune responses (Song et al., 2008; Chiu et al., 2009; Aguilar-Yáñez et al., 2010; Khurana et al., 2010b; 2011b; DuBois et al., 2011; Xuan et al., 2011; Verma et al., 2012; Hong et al., 2013; Sánchez-Arreola et al., 2013). Comparative studies on antigenicity and TLR5 activity of STF2.H5, STF2R0.H5, STF2R3.H5 fusion proteins (Table 2) showed that both HA protein and flagellin are better presented in the R3 construct than in the C-term one and that decreased antigenicity of the $\mathrm{R} 0$ construct is accompanied by the loss of the TLR 5 
activity (Song et al., 2009). Substantially improved antigenicity of HA protein in the R3 configuration in comparison to the C-term one was also observed in the immunoreactivity studies of STF2:H1pdm09 fusion protein (Liu et al., 2011). However, the strongest immunoreactivity was found for the R3.2×H1pdm09 construct as two HA copies were present in the fusion protein molecule. Screening of the prototype $\mathrm{gH}$ constructs (Table 2) produced to be coupled with Q $\beta-V L P s$ revealed that gH_A and $\mathrm{gH}$ _B proteins bind to the sialic acid on the fetuin glycoproteins indicating that receptor-binding activity of HA was preserved (Jegerlehner et al., 2013).

Taking into account the importance of higher-order structure of the vaccine HAs for induction of protective immune responses, the oligomeric status of bacteria-expressed HA proteins was studied in addition to antigenicity testing. It was reported that refolded and purified HA1 subunit fragments (1-330 aa, 1-320 aa) of HAs from H1N1pdm09 and H5N1 viruses (Table 1 ), in contrast to the shorter H5 HA fragment (28320 aa), existed in the majority as trimers and oligomers (Khurana et al., 2010b; 2011a; 2011b; Verma et al., 2012). It has been shown that oligomerization of the HA proteins involves conservative amino acids of the signal sequence and that the 1-320 aa fragments of HAs form more stable oligomers than the 1-330 aa ones. The HA1 subunit-based design was used successfully to obtain properly folded HA proteins from H1pdm09, H5, H7 and H3 HAs (Table 1). All these proteins were shown to form functional oligomers $(\geq 70 \%)$ which generate rosette-like structures composed of trimers resembling those formed by the native HA isolated from the influenza viruses. The refolded and purified HA1 subunit-based proteins, shorter than that generated by Khurana and coworkers (2010b, 2011a, 2011b) and Verma and coworkers (2012), and expressed bacterially without the signal sequence (Table 1), did not form oligomers and existed as monomers containing the properly folded globular domain of HA (Aguilar-Yáñez et al., 2010; DuBois et al., 2011; Xuan et al. 2011), or as dimers due to the linker peptide (Sánchez-Arreola et al., 2013). In spite of the presence of the signal sequence, the properly folded ectodomain-based HA protein (1-480 aa, Table 3) was monomeric and did not display oligomeric HA activities, such as binding to fetuin and hemagglutination (Khurana et al., 2010b). On the other hand, it was shown that properly folded $\mathrm{gH}$ proteins induce agglutination of erythrocytes with comparable efficiency to influenza viral particles upon coupling to $\mathrm{Q} \beta$ VLPs (Jegerlehner et al., 2013).

It was reported that bacterially expressed HA2 subunit-based proteins (Table 4), containing sequences exclusively from the HA2 subunit ectodomain, spontaneously fold into the low $\mathrm{pH}$ conformation and trimerize forming stable structures corresponding to that of the native HA in its fusogenic state (Chen et al., 1995; 1999; Kim et al., 2011). By introducing the regions of the HA1 subunit that are in close spatial proximity to the HA2 subunit in the whole HA molecule as well as the rationally designed mutations to the HA2 subunit-based proteins (Table 4), it was possible to obtain soluble immunogens containing the HA2 subunit fragment in the desired neutral $\mathrm{pH}$, pre-fusion conformation (Bommakanti et al., 2010, 2012). This was evidenced by spectroscopic analysis and reactivity studies with broadly neutralizing Mabs. Moreover, it was shown that HA6 design is better than the HAOHA6 one, as the former is trimeric in the majority and the latter is largely aggregated.

\section{Immunogenicity}

Immunization studies showed that bacterial HAs are immunogenic and in animals they elicit HA-specific antibodies. However, more relevant to the evaluation of the protective efficacy of HA proteins are their abilities to induce functional antibodies: inhibiting hemagglutination and neutralizing influenza viruses. Titers of these antibodies measured by the hemagglutination inhibition (HI) and the microneutralization $(\mathrm{MN})$ tests are considered as correlates of protection against influenza. It was demonstrated that proteins based on the HA1 subunit (Table 1) as well as the fragment (1-480 aa) of the HA ectodomain (Table 3), for which conformational integrity was proven by structure and/or antigenicity studies, are capable of inducing antibodies inhibiting hemagglutination by homologous viruses and/or neutralizing these viruses under in vitro conditions (Aguilar-Yáñez et al. 2010; Khurana et al. 2010b; 2011a; 2011b; Xuan et al., 2011; Verma et al., 2012). The HI antibody-inducing ability was also shown for recombinant $60 \mathrm{kDA}$ full-length ectodomain protein (Table 3) with not yet demonstrated biochemical properties (Biesova et al., 2009).

In immunization studies with the 1-320 aa fragment of H5 HA (Table 1), it was shown that anti-H5 sera are neutralizing not only against the virus from which the vaccine antigen was derived, but also against viruses belonging to other H5N1 HPAIV clades (Khurana et al., 2011a; 2011b). Comparative studies of antisera induced by vaccination with oligomeric (1-320 aa) and monomeric (28-320 aa) H5 HA proteins (Table 1) have documented that induction of high-titer antibodies with broad cross-clade neutralizing activity is related to antigen oligomerization (Khurana et al., 2011b). The significance of oligomerization for immune response quality was further confirmed in vaccination trials with the monomeric and oligomeric forms of the 1-320 aa H5 HA protein (Table 1) obtained by size exclusion chromatography of refolded and affinity purified bacteria-expressed antigen (Verma et al., 2012). Oligomeric protein was superior to the monomeric one in eliciting high-avidity anti-HA and HI antibodies against both the homologous and the heterologous antigens.

The early studies on immunogenicity of flagellin adjuvanted HA proteins carried out with STF2.H1_SI protein (Table 2) to immunize mice and rabbits, showed the ability of the protein to induce high titers of antibodies inhibiting hemagglutination and neutralizing viruses in vitro (Song et al., 2008). Subsequent experiments with various constructs of STF2:HA fusion proteins (Table 2) have proven that placement of the globular domain within flagellin substantially affects the titer of $\mathrm{HI}$ antibodies induced by the respective antigens (Song et al., 2009; Liu et al., 2011ł 2012). Protein in the R0 configuration, as the exception, was not capable of inducing significant levels of $\mathrm{HI}$ antibodies in mice consistently with its low TLR5 activity. Vaccine candidates against H5N1 and $\mathrm{H} 1 \mathrm{~N} 1 \mathrm{pdm} 09$ viruses in the R3 configuration were more effective in inducing protective $\mathrm{HI}$ antibody titers in animals than those in the C-term one. Immunogenicity of STF2R3.H5_IN and STF2R3.H1_CA antigens, but not of STF2R3.H5_AN protein, was further increased by coupling the second HA molecule to the C-terminus of STF2.

Immunogenicity of $\mathrm{gH}$ proteins (Table 2) were examined both before and after coupling to Q $\beta$-VLPs (Jegerlehner et al., 2013; Skibinski et al., 2013). The vaccine candidates when used to immunize mice evoked significantly higher native HA-specific IgG, HI and neutraliz- 
ing antibody titers than their unconjugated counterparts. Immunization studies with Q $\beta-g H$ VLPs containing or devoid of ssRNA in the mouse model showed that $\mathrm{Q} \beta$-based vaccines induce a potent $\mathrm{T}$ helper cell type 1 (Th1) response and that the presence of ssRNA in $\mathrm{Q} \beta$ VLPs is responsible for an increased Th1 bias (Skibinski et al., 2013).

\section{Efficacy}

The ability of bacteria-expressed H1pdm09 HA immunogens to confer protection against 2009 pandemic influenza was studied in the ferret (Aguilar-Yáñez et al., 2010; Khurana et al., 2010b; Skibinski et al., 2013) and in the mouse (Xuan et al., 2011; Skibinski et al., 2013) models by challenging the vaccinated animals with homologous H1N1pdm09 virus strains which are relatively mild, and thus did not cause severe disease in animals. It was shown that immunization with proteins based on the HA1 subunit (1-330 aa, 57-264 aa, 63-286 aa; Table 1), HA ectodomain (1-480 aa; Table 3) as well as with Q $\beta-g H 1 p d m 09$ VLPs (Table 2) induce protective immune responses against influenza in mice and ferrets (Aguilar-Yáñez et al., 2010; Khurana et al., 2010b; Xuan et al., 2011; Skibinski et al., 2013). Protective effects of vaccination were evident in that the animals did not get sick from flu or the course of the disease was milder than in unvaccinated controls.

Various formats of STF2:H1pdm09 fusion proteins (Table 2) were examined for vaccination efficacy in the lethal challenge experiment with the mouse adapted H1N1pdm09 virus (Liu et al., 2011). All tested fusion proteins conferred protection against mortality when given to mice at $3 \mu \mathrm{g}$ and even at as little as $0.3 \mu \mathrm{g}$ of antigen per dose. However, survival rates in the mice vaccinated at $0.03 \mu \mathrm{g}$-doses showed consistently with the predetermined immunogenicity rank that the order of the relative effectiveness of the three formats is: $\mathrm{R} 3.2 \times \mathrm{H} 1>$ R3 > C-term.

In most of the challenge experiments testing bacterial H1pdm09 HAs the viral loads in the nasal lavages of ferrets (Khurana et al., 2010b; Skibinski et al., 2013), or in the lungs of mice (Liu et al., 2011; Skibinski et al., 2013) following H1N1pdm09 virus challenge were determined. This led to the conclusion that vaccination leads to substantial reduction of viral titers in both ferrets and mice. Altogether these results demonstrated that vaccination with bacterially expressed vaccine HA could provide control of influenza virus infection and transmission rates in a population under pandemic conditions.

The HA1 subunit-based bacterial HAs originated from H5N1/VN virus (Table 1): largely oligomeric, 1-320 aa, only monomeric, 28-320 aa, (Khurana et al., 2011b) as well as oligomeric and monomeric fractions of the 1-320 aa protein (Verma et al., 2012) were used to immunize ferrets prior to the challenge with homologous (H5N1/ $\mathrm{VN}$, clade 1) and/or heterologous (H5N1/WS/Mong, clade 2.2) HPAIVs. Ferrets vaccinated with largely oligomeric rHA were highly protected from lethality against homologous and heterologous challenges, resulting in $100 \%$ and $80 \%$ survival rates, respectively, while those vaccinated with the oligomeric fraction of $\mathrm{rHA}$ were fully protected from both strains of HP H5N1 viruses $(100 \%$ survival rates). The level of animal protection after immunization with entirely oligomeric rHA was the same as observed in the groups vaccinated with the adjuvanted licensed inactivated-H5N1 subunit vaccine. In contrast, both the 28-320 aa rHA which exists as a monomer and the monomeric fraction of the $1-320$ aa protein were not very protective: only $20 \%$ and $33 \%$ of animals survived after a homologous challenge, respectively. As few as $17 \%$ of animals vaccinated with the monomeric immunogen (1-320 aa) survived after a heterologous challenge. In addition, the challenge experiments revealed that immunization of ferrets with largely or entirely oligomeric rHA (1-320 aa) reduced viral loads in the nasal washes following a challenge with H5N1 HPAIVs. Moreover, viral loads after a heterologous $\mathrm{H} 5 \mathrm{~N} 1$ challenge were more efficiently controlled in ferrets vaccinated with oligomeric fraction of rHA (1-320 aa) than in ferrets vaccinated with the commercial vaccine against $\mathrm{H} 5 \mathrm{~N} 1$, and this was related to the induction of higher-avidity antibodies against the HA1 subunit. Therefore, the success of vaccination with oligomeric forms of HA proteins is also due to the capacity to reduce viral replication in the upper respiratory tract. This is important for the prevention of lung infection as well as for the limiting virus transmission.

Four formats (C-term, R0, R3, R3.2×HA) of STF2:H5 fusion proteins (Table 2) were examined for efficacy by the lethal homologous challenge experiments in the mouse and/or ferret models (Song et al., 2009; Liu et al., 2012). The protein in R0 configuration failed to induce the protective immune response in mice $(0$ or $10 \%$ survival rates). In contrast, STF2:H5 fusion protein formats other than R0 were highly efficacious in mice and ferrets, resulting in 100\% (exceptionally 93\%) survival rates for certain immunization schemes. However, immunization of mice at lower-dosage regimens demonstrated that the R3 format of protein is more effective in protecting mice from disease and death than the prototype C-term one and that the protein in the $\mathrm{R} 3.2 \times \mathrm{HA}$ configuration is the most effective, being efficacious even at sub-microgram doses. Importantly, it was shown that STF2:H5 fusion proteins are able to reduce the virus titers in the brains, lungs and nasal wash samples of vaccinated and challenged mice and ferrets, respectively, which could predictably reduce viral transmission.

The challenge experiments with bacterially produced H5 HA immunogens were also performed in chickens, being the main target for vaccination against $\mathrm{H} 5 \mathrm{N1}$ HPAIV. In the high-dose regimen, full protection was achieved with the $97 \mathrm{kDA}$ msyB:H5 protein (Table 3) similar to that obtained with a commercial vaccine against H5N1 HP viruses (Xie et al., 2009). The ability to induce a protective immune response in chickens resulting in high rates of survival in challenge experiments with homologous and heterologous HPAIVs, was shown with bacterial H5 HA designed and produced in the Institute of Biotechnology and Antibiotics (Warsaw, Poland). Currently, the HA protein and the vaccine against influenza are subject to the patent procedure.

Several vaccine candidates based on the $\mathrm{H} 1$ and $\mathrm{H} 3$ rHAs were examined for efficacy by homologous and/ or heterologous challenge experiments with the use of $\mathrm{H} 1 \mathrm{~N} 1 / \mathrm{PR} 8$ or $\mathrm{H} 3 \mathrm{~N} 2$ viruses for animal infection. The early STF2:HA immunogen in the $\mathrm{C}$-term configuration - STF2.H1_PR8 (Table 2) was administered to mice subsequently infected with the mouse adapted H1N1/PR8 virus (Song et al., 2008). All vaccinated animals survived the lethal challenge and showed neither weight loss nor other signs of morbidity.

Type A and B gH proteins (Table 2) were examined in challenge experiments before and after coupling to Q $\beta-V L P s$ (Jegerlehner et al., 2013). Mice immunized with gH1_B_PR8 proteins quickly succumbed to H1N1/PR8 virus infection, and those immunized with gH1_A_PR8 and gH1_A_CA were only partially protected. In con- 
trast, all mice immunized with $\mathrm{gH}$ proteins conjugated to QB-VLPs at the same dosage regimen survived after infection with challenging viruses. Importantly, immunization of mice with the most promising prototype influenza vaccines: QB-gH_A1_PR8 and QB-gH_A2_PR8 resulted in complete protection against lethal infection not only with the homologous, but also with highly drifted viral strains. The broad protective potential of candidate vaccines based on $\mathrm{Q} \beta$-gH VLPs was further strongly confirmed with Q $\beta-g H 1$ A_CA protein applied for mouse vaccination before infection with $\mathrm{H} 1 \mathrm{~N} 1 / \mathrm{PR} 8$ virus. Moreover, it was shown that protection from mortality and largely from morbidity against both homologous and heterologous influenza virus strains can be achieved with low, even sub-microgram doses of antigen.

The HA6- or HAOHA6-like stem domain immunogens based on the HA sequences of various H1N1, H1N1pdm09 and H3N2 influenza virus strains (Table 4) successfully protected mice from homologous viral challenge, resulting in 100\% survival rates at certain dosage regimens. High survival rates were also observed in mice immunized with H3HA6_Phil protein and infected with heterologous $\mathrm{A} / \mathrm{HK} / 68(\overline{\mathrm{H}} 3 \mathrm{~N} 2)$ virus $(80 \%)$ as well as those immunized with H1HA6_NC and H1HA6_CA proteins, and infected with highly drifted H1N1/PR $\overline{8}$ viral strain $(90 \%)$. However, H3HA6_HK failed to confer protection against a heterosubtype $\mathrm{H} 1 \mathrm{~N} 1 / \mathrm{PR} 8$ influen$\mathrm{za}$ virus. These results led to the conclusion that stem domain immunogens are able to provide intra- but not inter-subtype protection.

\section{Clinical studies}

VaxInnate has already generated clinical data for its bacterially produced influenza vaccines based on proprietary Toll-like Receptor technology. The first one was a monovalent seasonal vaccine (VAX125) containing $\mathrm{H} 1 \mathrm{~N} 1 / \mathrm{SI}$ virus HA protein genetically fused to flagellin in the initial C-term configuration (Table 2). With the VAX125, the seroconversion rates: $64 \%$ in healthy young adults (18-49 years old) at $0.5 \mu \mathrm{g}$ to $2 \mu \mathrm{g}$ doses and $75 \%$ in elderly subjects (65-84 years old) at $5 \mu \mathrm{g}$ and $8 \mu \mathrm{g}$ doses were achieved resulting in high seroprotection rates: $91 \%$ and $98 \%$, respectively (Treanor et al. 2010; Taylor, et al. 2011). Importantly, the vaccine was generally well tolerated, although a few instances of flulike symptoms at doses 3-8 $\mu \mathrm{g}$ were noticed. Altogether, these results showed that the new vaccine is safe and highly immunogenic even in the elderly population, a group that is typically less responsive to influenza vaccines. Moreover, the efficacious doses of VAX125 were substantially lower than those used for conventional vaccines against influenza e.g. Fluzone owing to the adjuvant activity of flagellin which, on the other hand, was also responsible for the improved immune response in the elderly.

STF2:H1pdm09 fusion proteins in C-term, R3 and R3.2 $\times$ HA configurations contained in VAX128A, VAX128B and VAX128C, respectively (Table 2), and were evaluated for safety and immunogenicity successively in rabbits and in humans (Taylor et al., 2012). In both models, it was found that replacing the HA antigen in the D3 position of flagellin in VAX128B and VAX128C produces a vaccine that was at least as immunogenic and better tolerated at higher doses than the C-terminal fusion construct (VAX128A). VAX128C selected for the second study caused high seroconversion (79\%) and seroprotection $(92 \%)$ rates in subjects $18-64$ years old at the doses of $1.25 \mu \mathrm{g}$ and $2.5 \mu \mathrm{g}$.
High levels of immune responses at low doses of antigen, and the relative ease of the production associated with bacterial expression suggest that VaxInnate's technology can represent an effective strategy for enhancing the global influenza vaccine supply. VaxInnate announced that it can generate at least 50 million doses within 5-6 months, with first doses becoming available as soon as after 12 weeks. In both a rapidly emerging pandemic and in seasonal virus mismatch events, such speed is a distinct advantage. Currently, VaxInnate's active pandemic programs focus on $\mathrm{H} 5 \mathrm{~N} 1$ and $\mathrm{H} 7 \mathrm{~N} 9$ candidates and research on seasonal influenza vaccine is still continuing. In March 2014 VaxInnate began a phase I clinical trial to evaluate a quadrivalent recombinant vaccine for prevention of seasonal flu - VAX2012Q.

Another bacterially produced HA-based immunogen advanced into clinical study is the H1N1 influenza vaccine candidate based on Cytos' proprietary bacteriophage Q $\beta$-VLP technology. Started in May 2013, the first phase I clinical trial was conducted by the Agency for Science, Technology and Research (A*Star) and Cytos Biotechnology. A*Star reported that the novel vaccine was safe, well tolerated and induced immune responses which were comparable to those of approved seasonal influenza vaccines.

\section{CONCLUSIONS}

The technology for producing large quantities of proteins in bacteria, including biopharmaceuticals, has been practiced for over two decades. Exploitation of this technology for the production of the HA-based vaccines against influenza seems to be hampered for a long time by the widely accepted view that glycosylation determines the correct structure of the protein. More recently, experimental data for both considerable independence of HA folding from the glycosylation status, and the successful production of bacterial HAs have been published. In contrast to full-length or ectodomain-based HAs produced in eukaryotic expression system, the vast majority of bacterially produced HA proteins have been based on the HA1 subunit and only a few examples of bacterial HAs based on the ectodomain or the HA2 subunit have been reported so far. The recombinant proteins, derived from the 2009 H1N1 pandemic, highly pathogenic $\mathrm{H} 5 \mathrm{~N} 1$, seasonal $\mathrm{H} 1 \mathrm{~N} 1$ and $\mathrm{H} 3 \mathrm{~N} 2$ as well as prototype H1N1/PR8 influenza viruses, have been efficiently expressed in the form of inclusion bodies.

The studies of refolded and purified HA proteins proved that bacterial HAs can be valuable vaccine antigens. Although devoid of the regions participating in the formation of higher-order structures of HA during its biosynthesis in host cells, bacterial HAs can adopt the conformation similar to that displayed by the native protein. In addition, some of these proteins were shown to form functional oligomers, what has a proven beneficial effect on both protective efficacy and dose sparing. Consistently with the biochemical characteristics, immunization studies clearly demonstrated the potential of the bacterially produced vaccine candidates to confer intra-subtype protection against influenza viruses, including highly drifted ones as well as to provide control of virus infection and transmission rates in animals. Moreover, clinical studies with vaccines based on proprietary Toll-like Receptor (VaxInnate) and bacteriophage Q $\beta$-VLPs (Cytos Biotechnology) technologies generated positive data. 
The data so far published indicate that the success in the bacterial production of the vaccine antigens strongly depends on the HA fragment chosen for expression as well as on the applied refolding method. For short fragments of HA, it was well documented that careful selection of the peptides from the protein sequence to be expressed with the target HA regions, such as the globular domain or the HA2 subunit, is prerequisite to obtain properly folded proteins with satisfactory efficiency. It was also shown, that the expression of specified-length fragments from HA1 subunit with the signal sequences, which are absent in the mature viral HAs, is essential for protein oligomerization. In some vaccine projects, one should consider the introduction of rationally designed mutations to obtain protein adopting the desired conformation, as it was evidenced for the stem domain immunogens. The determinations of the HA sequence for the antigen production in bacteria, especially those based on the short HA fragments, were often preceded by the analyses of the HA structure in silico. Experience with bacterial HAs shows that in silico modeling is helpful in the selection of protein sequences to be expressed bacterially, but does not guarantee success of the design. The value of refolded and purified rHAs needs to be verified through extensive studies of structure, the ability to bind to sialic acid-containing receptors, antigenicity, immunogenicity and finally efficacy in the challenge experiments and clinical trials. Once the HA protein is validated, the precise selection of the sequence from HA of various influenza A virus strains seems to be possible simply through structural alignment of the prototype HA fragment with the target HA proteins.

The vast majority of valuable, bacterially produced, vaccine antigens have been expressed with His-tags and purified by metal affinity chromatography, which is both expensive and poses the safety problem related to the presence of even trace amounts of metal in the final products. Thus, the development of appropriate purification procedures is needed to take advantage of bacterial cell expression technology for enhancing the supply in vaccines against influenza, especially for a pandemic. The research on subunit vaccines against influenza based on bacterial HAs is still continuing. The exemplification is the patent pending $\mathrm{HA}$ protein designed and bacterially produced in the Institute of Biotechnology and Antibiotics (Warsaw, Poland).

\section{Acknowledgements}

This work was funded by European Funds Portal Innovative Economy "Centre of medicinal product biotechnology. Package of innovative biopharmaceuticals for human and animal therapy and prophylactics." POIG.01.01.02.-14-007/08-06.

\section{REFERENCES}

Aguilar-Yáñez JM, Portillo-Lara R, Mendoza-Ochoa GI, García-Echauri SA, López-Pacheco F, Bulnes-Abundis D, Salgado-Gallegos J, Lara-Mayorga IM, Webb-Vargas Y, León-Angel FO, Rivero-Aranda RE, Oropeza-Almazán Y, Ruiz-Palacios GM, Zertuche-Guerra MI, DuBois RM, White SW, Schultz-Cherry S, Russell CJ, Alvarez MM (2010) An influenza A/H1N1/2009 hemagglutinin vaccine produced in Escherichia coli. PLoS One 5: e11694.

Atsmon J, Kate-Ilovitz E, Shaikevich D, Singer Y, Volokhov I, Haim KY, Ben-Yedidia T (2012) Safety and immunogenicity of multimeric-001 - a novel universal influenza vaccine. J Clin Immunol 32: 595-603.

Baneyx F, Mujacic M (2004) Recombinant protein folding and misfolding in Escherichia coli. Nat Biotechnol 22: 1399-1408.
Barbey-Martin C, Gigant B, Bizebard T, Calder LJ, Wharton SA, Skehel JJ, Knossow M (2002) An antibody that prevents the hemagglutinin low $\mathrm{pH}$ fusogenic transition. Virology 294: 70-74.

Biesova Z, Miller MA, Schneerson R, Shiloach J, Green KY, Robbins JB, Keith JM (2009) Preparation, characterization, and immunogenicity in mice of a recombinant influenza $\mathrm{H} 5$ hemagglutinin vaccine against the avian H5N1 A/Vietnam/1203/2004 influenza virus. Vaccine 27: 6234-6238.

Bizebard T, Gigant B, Rigolet P, Rasmussen B, Diat O, Bösecke P, Wharton SA, Skehel JJ, Knossow M (1995) Structure of influenza virus haemagglutinin complexed with a neutralizing antibody. Nature 376: 92-94.

Bommakanti G, Citron MP, Hepler RW, Callahan C, Heidecker GJ, Najar TA, Lu X, Joyce JG, Shiver JW, Casimiro DR, ter Meulen J, Liang X, Varadarajan R (2010) Design of an HA2-based Escherichia coli expressed influenza immunogen that protects mice from pathogenic challenge. Proc Natl Acad Sci USA 107: 13701-13706.

Bommakanti G, Lu X, Citron MP, Najar TA, Heidecker GJ, ter Meulen J, Varadarajan R, Liang X (2012) Design of Escherichia coli-expressed stalk domain immunogens of H1N1 hemagglutinin that protect mice from lethal challenge. J Virol 86: 13434-13444.

Bosch BJ, Bodewes R, de Vries RP, Kreijtz JH, Bartelink W, van Amerongen G, Rimmelzwaan GF, de Haan CA, Osterhaus AD, Rottier PJ (2010) Recombinant soluble, multimeric HA and NA exhibit distinctive types of protection against pandemic swine-origin 2009 $\mathrm{A}(\mathrm{H} 1 \mathrm{N1})$ influenza virus infection in ferrets. J Virol 84: 1036610374.

Bright RA, Ross TM, Subbarao K, Robinson HL, Katz JM (2003) Impact of glycosylation on the immunogenicity of a DNA-based influenza H5 HA vaccine. Virology 308: 270-278.

Chen J, Lee KH, Steinhauer DA, Stevens DJ, Skehel JJ, Wiley DC (1998) Structure of the hemagglutinin precursor cleavage site, a determinant of influenza pathogenicity and the origin of the labile conformation. Cell 95: 409-417.

Chen J, Skehel JJ, Wiley DC (1999) N- and C-terminal residues combine in the fusion- $\mathrm{pH}$ influenza hemagglutinin $\mathrm{HA}(2)$ subunit to form an $\mathrm{N}$ cap that terminates the triple-stranded coiled coil. Proc Natl Acad Sci USA 96: 8967-8972.

Chen J, Wharton SA, Weissenhorn W, Calder LJ, Hughson FM, Skehel JJ, Wiley DC (1995) A soluble domain of the membrane-anchoring chain of influenza virus hemagglutinin (HA2) folds in Eschericbia coli into the low-pH-induced conformation. Proc Natl Acad Sci USA 92: 12205-12209.

Chiu FF, Venkatesan N, Wu CR, Chou AH, Chen HW, Lian SP, Liu SJ, Huang CC, Lian WC, Chong P, Leng CH (2009) Immunological study of HA1 domain of hemagglutinin of influenza H5N1 virus. Biochem Biophys Res Commun 383: 27-31.

Cornelissen LA, de Vries RP, de Boer-Luijtze EA, Rigter A, Rottier PJ, de Haan CA (2010) A single immunization with soluble recombinant trimeric hemagglutinin protects chickens against highly pathogenic avian influenza virus H5N1. PLoS One 5: e10645.

Davis AR, Bos T, Ueda M, Nayak DP, Dowbenko D, Compans RW (1983) Immune response to human influenza virus hemagglutinin expressed in Escherichia coli. Gene 21: 273-284.

Davis AR, Nayak DP, Ueda M, Hiti AL, Dowbenko D, Kleid DG (1981) Expression of antigenic determinants of the hemagglutinin gene of a human influenza virus in Escherichia coli. Proc Natl Acad Sci USA 78: 5376-5380.

de Vries RP, Smit CH, de Bruin E, Rigter A, de Vries E, Cornelissen LA, Eggink D, Chung NP, Moore JP, Sanders RW, Hokke CH, Koopmans M, Rottier PJ, de Haan CA (2012) Glycan-dependent immunogenicity of recombinant soluble trimeric hemagglutinin. J Virol 86: 11735-11744.

DuBois RM, Aguilar-Yañez JM, Mendoza-Ochoa GI, Oropeza-Almazán Y, Schultz-Cherry S, Alvarez MM, White SW, Russell CJ (2011) The receptor-binding domain of influenza virus hemagglutinin produced in Escherichia coli folds into its native, immunogenic structure. J Virol 85: 865-872.

Dukhovlinov I, Al-Shekhadat R, Fedorova E, Stepanova L, Potapchuk M, Repko I, Rusova O, Orlov A, Tsybalova L, Kiselev O (2013) Study of immunogenicity of recombinant proteins based on hemagglutinin and neuraminidase conservative epitopes of influenza A virus. Med Sci Monit Basic Res 19: 221-227.

Dumon-Seignovert L, Cariot G, Vuillard L (2004) The toxicity of recombinant proteins in Escherichia coli: a comparison of overexpression in BL21(DE3), C41(DE3), and C43(DE3). Protein Expr Purif 37: 203-206.

Ekiert DC, Bhabha G, Elsliger MA, Friesen RH, Jongeneelen M, Throsby M, Goudsmit J, Wilson IA (2009) Antibody recognition of a highly conserved influenza virus epitope. Science 324: 246-251.

Farahmand B, Khodabandeh M, Mahboudi F, Fotouhi F, Saleh M, Barkhordari F, Tabatabaian M, Nasab FP, Kheiri MT (2012) Influenza virus hemagglutinin: a model for protein $\mathrm{N}$-glycosylation in recombinant Escherichia coli. Intervirology 55: 219-224.

Fleury D, Barrère B, Bizebard T, Daniels RS, Skehel JJ, Knossow M (1999) A complex of influenza hemagglutinin with a neutralizing an- 
tibody that binds outside the virus receptor binding site. Nat Struct Biol 6: 530-534.

Ha Y, Stevens DJ, Skehel JJ, Wiley DC (2002) H5 avian and H9 swine influenza virus haemagglutinin structures: possible origin of influenza subtypes. EMBO J 21: 865-875.

Hong M, Lee PS, Hoffman RM, Zhu X, Krause JC, Laursen NS, Yoon SI, Song L, Tussey L, Crowe JE Jr, Ward AB, Wilson IA (2013) Antibody recognition of the pandemic H1N1 Influenza virus hemagglutinin receptor binding site. J Virol 87: 12471-12480.

Horthongkham N, Srihtrakul T, Athipanyasilp N, Siritantikorn S, Kantakamalakul W, Poovorawan Y, Sutthent R (2007) Specific antibody response of mice after immunization with COS-7 cell derived avian influenza virus (H5N1) recombinant proteins. I Immune Based Ther Vaccines 5: 10.

Jegerlehner A, Zabel F, Langer A, Dietmeier K, Jennings GT, Saudan $\mathrm{P}$, Bachmann MF (2013) Bacterially produced recombinant influenza vaccines based on virus-like particles. PLoS One 8: e78947.

Jeon SH, Arnon R (2002) Immunization with influenza virus hemagglutinin globular region containing the receptor-binding pocket. $V i$ ral Immunol 15: 165-176.

Johansson BE, Brett IC (2007) Changing perspective on immunization against influenza. Vaccine 25: 3062-3065.

Johansson BE, Bucher DJ, Kilbourne ED (1989) Purified influenza virus hemagglutinin and neuraminidase are equivalent in stimulation of antibody response but induce contrasting types of immunity to infection. J Virol 63: 1239-1246.

Khurana S, Chearwae W, Castellino F, Manischewitz J, King LR, Honorkiewicz A, Rock MT, Edwards KM, Del Giudice G, Rappuoli R, Golding H (2010a) Vaccines with MF59 adjuvant expand the antibody repertoire to target protective sites of pandemic avian H5N1 influenza virus. Sci Transl Med 2: $15 \mathrm{ra} 5$.

Khurana S, Larkin C, Verma S, Joshi MB, Fontana J, Steven AC, King LR, Manischewitz J, McCormick W, Gupta RK, Golding H (2011a) Recombinant HA1 produced in E. coli forms functional oligomers and generates strain-specific SRID potency antibodies for pandemic influenza vaccines. Vaccine 29: 5657-5665.

Khurana S, Suguitan AL Jr, Rivera Y, Simmons CP, Lanzavecchia A, Sallusto F, Manischewitz J, King LR, Subbarao K, Golding H (2009) Antigenic fingerprinting of H5N1 avian influenza using convalescent sera and monoclonal antibodies reveals potential vaccine and diagnostic targets. PLoS Med 6: e1000049.

Khurana S, Verma S, Verma N, Crevar CJ, Carter DM, Manischewitz J, King LR, Ross TM, Golding H (2010b) Properly folded bacterially expressed H1N1 hemagglutinin globular head and ectodomain vaccines protect ferrets against H1N1 pandemic influenza virus. PLoS One 5: e11548.

Khurana S, Verma S, Verma N, Crevar CJ, Carter DM, Manischewitz J, King LR, Ross TM, Golding H (2011b) Bacterial HA1 vaccine against pandemic H5N1 influenza virus: evidence of oligomerization, hemagglutination, and cross-protective immunity in ferrets. $J$ Virol 85: 1246-1256.

Kim CS, Epand RF, Leikina E, Epand RM, Chernomordik LV (2011) The final conformation of the complete ectodomain of the HA2 subunit of influenza hemagglutinin can by itself drive low $\mathrm{pH}$-dependent fusion. J Biol Chem 286: 13226-13234.

Krystal M, Elliott RM, Benz EW Jr, Young JF, Palese P (1982) Evolution of influenza A and B viruses: conservation of structural features in the hemagglutinin genes. Proc Natl Acad Sci USA 79: 48004804.

Lamb RA, Choppin PW (1983) The gene structure and replication of influenza virus. Annu Rev Biochem 52: 467-506.

Li H, Ding J, Chen YH (2003) Recombinant protein comprising multineutralizing epitopes induced high titer of antibodies against influenza A virus. Immunobiology 207: 305-313.

Liu G, Song L, Reiserova L, Trivedi U, Li H, Liu X, Noah D, Hou F, Weaver B, Tussey L (2012) Flagellin-HA vaccines protect ferrets and mice against $\mathrm{H} 5 \mathrm{~N} 1$ highly pathogenic avian influenza virus (HPAIV) infections. Vaccine 30: 6833-6838.

Liu G, Tarbet B, Song L, Reiserova L, Weaver B, Chen Y, Li H, Hou F, Liu X, Parent J, Umlauf S, Shaw A, Tussey L (2011) Immunogenicity and efficacy of flagellin-fused vaccine candidates targeting 2009 pandemic H1N1 influenza in mice. PLoS One 6: e20928.

Loeffen WL, de Vries RP, Stockhofe N, van Zoelen-Bos D, Maas R, Koch G, Moormann RJ, Rottier PJ, de Haan CA (2011) Vaccination with a soluble recombinant hemagglutinin trimer protects pigs against a challenge with pandemic (H1N1) 2009 influenza virus. Vaccine 29: 1545-1550.

McMurry JA, Johansson BE, De Groot AS (2008) A call to cellular $\&$ humoral arms: enlisting cognate $\mathrm{T}$ cell help to develop broadspectrum vaccines against influenza A. Hum Vaccin 4: 148-157.

Miroux B, Walker JE (1996) Over-production of proteins in Escherichia coli: mutant hosts that allow synthesis of some membrane proteins and globular proteins at high levels. J Mol Biol 260: 289-298.

Nayak DP, Davis AR, McQueen NL, Bos TJ, Jabbar MA, Sivasubramanian N, Lionelli $G$ (1985) Biological and immunological properties of haemagglutinin and neuraminidase expressed from cloned
cDNAs in prokaryotic and eukaryotic cells. Vaccine 3 (3 Suppl): 165-171.

Okuno Y, Isegawa Y, Sasao F, Ueda S (1993) A common neutralizing epitope conserved between the hemagglutinins of influenza A virus $\mathrm{H} 1$ and $\mathrm{H} 2$ strains. J Virol 67: 2552-2558.

Osterholm MT, Kelly NS, Manske JM, Ballering KS, Leighton TR, Moore KA (2012) The compelling need for game-changing influenza vaccines: an analysis of the influenza vaccine enterprise and recommendations for the future. University of Minnesota Center for Infectious Disease Research and Policy.

Park MH, Chang J (2012) Immunogenicity and protective efficacy of a dual subunit vaccine against respiratory syncytial virus and influenza virus. Immune Netw 12: 261-268.

Pica N, Palese P (2013) Toward a universal influenza virus vaccine: prospects and challenges. Annu Rev Med 64: 189-202.

Roberts PC, Garten W, Klenk HD (1993) Role of conserved glycosylation sites in maturation and transport of influenza A virus hemagglutinin. I Virol 67: 3048-3060.

Rudolph W, Ben Yedidia T (2011) A universal influenza vaccine: where are we in the pursuit of this "Holy Grail"? Hum V accin 7: 10-11.

Saelens X, Vanlandschoot P, Martinet W, Maras M, Neirynck S, Contreras R, Fiers W, Jou WM (1999) Protection of mice against a lethal influenza virus challenge after immunization with yeast-derived secreted influenza virus hemagglutinin. Eur J Biochem 260: 166-175.

Sánchez-Arreola PB, López-Uriarte S, Marichal-Gallardo PA, GonzálezVázquez JC, Pérez- Chavarría R, Soto-Vázquez P, López-Pacheco F, Ramírez-Medrano A, Rocha-Pizaña MR, Alvarez MM (2013) A baseline process for the production, recovery, and purification of bacterial influenza vaccine candidates. Biotechnol Prog 29: 896-908.

Shen S, Mahadevappa G, Oh HL, Wee BY, Choi YW, Hwang LA, Lim SG, Hong W, Lal SK, Tan YJ (2008) Comparing the antibody responses against recombinant hemagglutinin proteins of avian influenza A (H5N1) virus expressed in insect cells and bacteria. J Med Virol 80: 1972-1983.

Shih AC, Hsiao TC, Ho MS, Li WH (2007) Simultaneous amino acid substitutions at antigenic sites drive influenza A hemagglutinin evolution. Proc Natl Acad Sci USA 104: 6283-6288.

Skehel JJ, Cross K, Steinhauer D, Wiley DC (2001) Influenza fusion peptides. Biochem Soc Trans 29: 623-626.

Skehel JJ, Stevens DJ, Daniels RS, Douglas AR, Knossow M, Wilson IA, Wiley DC (1984) A carbohydrate side chain on hemagglutinins of Hong Kong influenza viruses inhibits recognition by a monoclonal antibody. Proc Natl Acad Sci USA 81: 1779-1783.

Skehel JJ, Wiley DC (2000) Receptor binding and membrane fusion in virus entry: the influenza hemagglutinin. Annu Rev Biochem 69: 531-569.

Skibinski DA, Hanson BJ, Lin Y, von Messling V, Jegerlehner A, Tee JB, Chye de H, Wong SK, Ng AA, Lee HY, Au B, Lee BT, Santoso L, Poidinger M, Fairhurst AM, Matter A, Bachmann MF, Saudan P, Connolly JE (2013) Enhanced neutralizing antibody titers and Th1 polarization from a novel Escherichia coli derived pandemic influenza vaccine. PLoS One 8: e76571.

Song L, Nakaar V, Kavita U, Price A, Huleatt J, Tang J, Jacobs A, Liu G, Huang Y, Desai P, Maksymiuk G, Takahashi V, Umlauf S, Reiserova L, Bell R, Li H, Zhang Y, McDonald WF, Powell TJ, Tussey L (2008) Efficacious recombinant influenza vaccines produced by high yield bacterial expression: a solution to global pandemic and seasonal needs. PLoS One 3: e2257.

Song L, Zhang Y, Yun NE, Poussard AL, Smith JN, Smith JK, Borisevich V, Linde JJ, Zacks MA, Li H, Kavita U, Reiserova L, Liu X, Dumuren K, Balasubramanian B, Weaver B, Parent J, Umlauf S, Liu G, Huleatt J, Tussey L, Paessler S (2009) Superior efficacy of a recombinant flagellin: $\mathrm{H} 5 \mathrm{~N} 1 \mathrm{HA}$ globular head vaccine is determined by the placement of the globular head within flagellin. Vaccine 27: 5875-5884.

Steel J, Lowen AC, Wang TT, Yondola M, Gao Q, Haye K, García-Sastre A, Palese P (2010) Influenza virus vaccine based on the conserved hemagglutinin stalk domain. MBio 1: e000818-10.

Suarez DL (2005) Overview of avian influenza DIVA test strategies. Biologicals 33: 221-226.

Sui J, Hwang WC, Perez S, Wei G, Aird D, Chen LM, Santelli E, Stec B, Cadwell G, Ali M, Wan H, Murakami A, Yammanuru A, Han T, Cox NJ, Bankston LA, Donis RO, Liddington RC, Marasco WA (2009) Structural and functional bases for broad-spectrum neutralization of avian and human influenza A viruses. Nat Struct Mol Biol 16: $265-273$.

Sylte MJ, Suarez DL (2009) Influenza neuraminidase as a vaccine antigen. Curr Top Microbiol Immunol 333: 227-241.

Taylor DN, Treanor JJ, Sheldon EA, Johnson C, Umlauf S, Song L, Kavita U, Liu G, Tussey L, Ozer K, Hofstaetter T, Shaw A (2012) Development of VAX128, a recombinant hemagglutinin (HA) influenza-flagellin fusion vaccine with improved safety and immune response. Vaccine 30: 5761-5769.

Taylor DN, Treanor JJ, Strout C, Johnson C, Fitzgerald T, Kavita U, Ozer K, Tussey L, Shaw A (2011) Induction of a potent immune response in the elderly using the TLR-5 agonist, flagellin, 
with a recombinant hemagglutinin influenza-flagellin fusion vaccine (VAX125, STF2.HA1 SI). Vaccine 29: 4897-4902.

Treanor JJ, Taylor DN, Tussey L, Hay C, Nolan C, Fitzgerald T, Liu G, Kavita U, Song L, Dark I, Shaw A (2010) Safety and immunogenicity of a recombinant hemagglutinin influenza-flagellin fusion vaccine (VAX125) in healthy young adults. Vaccine 28: 8268-8274.

Verma S, Dimitrova M, Munjal A, Fontana J, Crevar CJ, Carter DM, Ross TM, Khurana S, Golding H (2012) Oligomeric recombinant H5 HA1 vaccine produced in bacteria protects ferrets from homologous and heterologous wild-type $\mathrm{H} 5 \mathrm{~N} 1$ influenza challenge and controls viral loads better than subunit H5N1 vaccine by eliciting high-affinity antibodies. J Virol 86: 12283-12293.

Wacker M, Linton D, Hitchen PG, Nita-Lazar M, Haslam SM, North SJ, Panico M, Morris HR, Dell A, Wren BW, Aebi M (2002) Nlinked glycosylation in Campylobacter jejuni and its functional transfer into E. coli. Science 298: 1790-1793.

Wang CC, Chen JR, Tseng YC, Hsu CH, Hung YF, Chen SW, Chen CM, Khoo KH, Cheng TJ, Cheng YS, Jan JT, Wu CY, Ma C, Wong CH (2009) Glycans on influenza hemagglutinin affect receptor binding and immune response. Proc Natl Acad Sci USA 106: 18137-18142.

Wei CJ, Xu L, Kong WP, Shi W, Canis K, Stevens J, Yang ZY, Dell A, Haslam SM, Wilson IA, Nabel GJ (2008) Comparative efficacy of neutralizing antibodies elicited by recombinant hemagglutinin proteins from avian H5N1 influenza virus. J Virol 82: 6200-6208.

Weldon WC, Wang BZ, Martin MP, Koutsonanos DG, Skountzou I, Compans RW (2010) Enhanced immunogenicity of stabilized trimeric soluble influenza hemagglutinin. PLoS One 5: e12466.

Wiley DC, Skehel JJ (1987) The structure and function of the hemagglutinin membrane glycoprotein of influenza virus. Annu Rev Biochem 56: 365-394.

Wiley DC, Wilson IA, Skehel JJ (1981) Structural identification of the antibody-binding sites of Hong Kong influenza haemagglutinin and their involvement in antigenic variation. Nature 289: 373-378.

Wilson IA, Cox NJ (1990) Structural basis of immune recognition of influenza virus hemagglutinin. Annu Rev Immunol 8: 737-771.

Wilson IA, Skehel JJ, Wiley DC (1981) Structure of the haemagglutinin membrane glycoprotein of influenza virus at 3 A resolution. Nature 289: 366-373.

Xie QM, Ji J, Du LQ, Cao YC, Wei L, Xue CY, Qin JP, Ma JY, Bi YZ (2009) Preparation and immune activity analysis of H5N1 subtype avian influenza virus recombinant protein-based vaccine. Poult Sci 88: 1608-1615.

Xuan C, Shi Y, Qi J, Zhang W, Xiao H, Gao GF (2011) Structural vaccinology: structure-based design of influenza A virus hemagglutinin subtype-specific subunit vaccines. Protein Cell 2: 997-1005. 